\title{
Chapter 5 \\ Changing Climate and Outbreaks of Forest \\ Pest Insects in a Cold Northern Country, \\ Finland
}

\author{
Seppo Neuvonen and Heli Viiri
}

\begin{abstract}
Pest insect population dynamics are species specific and complex due to nonlinearities and interactions among different trophic levels. Consequently, the impacts of climate change on pests are also species specific and they are often difficult to predict. However, there are some clear examples of increasing forest pest risks due to a warming climate. The damage caused by the Eurasian spruce bark beetle has recently increased in Finland as a consequence of more frequent storm damage and longer growing seasons. In a warming climate, timely salvage and sanitation cuttings will be needed to guarantee the sustainability of the forestry. Several defoliating pests overwinter in the egg stage. Warmer winters may not kill the eggs and, therefore, the incidence of outbreaks is predicted to increase in the northern and continental areas. The most important societal implications will be due to Geometrids attacking subarctic mountain birch forests. Together with heavy reindeer grazing, Geometrids reduce the resilience of the ecosystem and they are threatening the sustainability of local livelihoods.
\end{abstract}

\subsection{Introduction}

In the Boreal zone, insects have had an essential role in the succession dynamics and in starting the succession process again in natural forests. However, in northern Europe the forests have been under intensive forestry for a long time. This has fragmented the landscape structure (Kouki et al. 2001), so that large and extensive insect outbreaks have occurred only rarely. The effects of changing climate on the population dynamics of insect pests are complex and species specific, and only some species are projected to increase in a warming climate (Björkman and Niemelä 2015).

Major pest insects are rare most of the time but they cause damage every now and then. For example, the plot level probability of pine sawfly outbreaks occurring at

\footnotetext{
S. Neuvonen $(\square) \bullet \mathrm{H}$. Viiri

Natural Resources Institute, Joensuu, Finland

e-mail: seppo.neuvonen@luke.fi
} 
least once in 20 years varied from about 10\% in the most fertile site types to 30-40\% in sub-xeric to xeric pine stands (Nevalainen et al. 2015).

Insect outbreaks can be classified into different types based on the population dynamics involved (Berryman et al. 1987):

(A) Regularly cyclic outbreaks: in northern Europe the Geometrid moths (Epirrita autumnata, Operophtera brumata) that defoliate mountain birches belong to this type (Haukioja et al. 1988).

(B) Eruptive outbreaks occur at irregular intervals. They may be triggered by specific environmental conditions (e.g. drought) and individual outbreaks are short. Pine sawflies (Neodiprion sertifer, Diprion pini) exemplify this type (Hanski 1987; Juutinen 1967). Another pest that has eruptive outbreaks is the European spruce bark beetle (Ips typographus), which is mainly regulated by resource availability (Økland and Bjørnstad 2006).

(C) Sustained outbreaks that may last for several years also occur at irregular intervals and they are triggered by environmental conditions. Although these kinds of outbreaks are rare in northern Europe, a recent example can be found in the damage caused by the large web-spinning sawfly (Acantholyda posticalis) in Finland and in Estonia (Pouttu and Silver 2016; Voolma et al. 2009).

A common feature to all outbreak types is that there is a difference of several orders of magnitude in insect densities during the low density (endemic) phase versus the outbreak (epidemic) phase (Berryman et al. 1987; Hanski 1987). Thus, the increase phase from endemic to epidemic densities requires normally at least 2 to 4 years, during which the environmental conditions must remain suitable for rapid population growth.

The climatic conditions in the boreal zone of northern Europe show high year to year variability. This variability can interact with other factors affecting the population dynamics of forest pest insects (Neuvonen and Virtanen 2015). Recent patterns in the outbreaks of the forest pests in relation to recent climatic changes are reviewed and discussed in this chapter.

\subsection{The Life Cycles of Pest Insects in Relation to Recent Climate Change in Finland}

Pest insects have complex life cycles and life stages. They live in a variety of microhabitats that experiencing very different climatic conditions. Consequently, considering the variable responses of different life stages to changing climate is essential to understand the impacts of climate change on pests (Kingsolver et al. 2011). Many of the forest defoliators in the Boreal zone overwinter in the egg stage and feed on early season foliage (Hunter 1991). The climatological winters (temperatures $<0{ }^{\circ} \mathrm{C}$ ) last several months in northern areas, experiencing occasionally extreme temperatures that are much lower than seasonal averages. These factors have important consequences for insect pests and for other ecological processes (Neuvonen et al. 1999; Williams et al. 2014). 
Extremely cold temperatures can kill eggs that are overwintering in the canopy (Austarå 1971; Nilssen and Tenow 1990). Consequently, higher winter minimum temperatures will increase the outbreak risks of pest species overwintering as eggs (Virtanen et al. 1996; Virtanen et al. 1998), but may not affect pests overwintering in the soil. The latter are normally protected by insulating snow cover and are not so sensitive to variations in air temperatures (Virtanen and Neuvonen 1999a).

The annual mean temperature in Finland has risen by a total of $2.3{ }^{\circ} \mathrm{C}$ from the mid-nineteenth century to the present (i.e. $0.14{ }^{\circ} \mathrm{C}$ per decade) (Mikkonen et al. 2015). The largest warming has been observed in winter temperatures. The spring (March-May) has also warmed more than the annual average, but during the summer months (i.e. during the time when most forest pests are actively feeding) there has been only very little or no warming (Mikkonen et al. 2015). The warming has not been even. For example, between the 1940s and the 1960s the climate did not warm (Mikkonen et al. 2015), but from the end of the 1960s onwards the mean daily temperatures have warmed on average by $0.3{ }^{\circ} \mathrm{C}$ per decade (Aalto et al. 2016).

The average temperature sums have increased by about $20 \%$ during the past 20 years and the incidence of storm damage has also increased during the last decade. This has increased the risk of spruce bark beetle damage, especially in southern Finland (Viiri and Neuvonen 2016). Given that the temperature during the summer months (June-August) has not increased much (Mikkonen et al. 2015; Neuvonen and Viiri 2015), the increase in temperature sums is mainly due to increases in spring and autumn temperatures.

When evaluating the potential impacts of climate change on forest pest insects, the following should be kept in mind:

(1) Forest insect pests do not generally experience the weather and climatic conditions recorded at weather stations. The effects of microclimates should be considered when estimating the ecological impacts of climate change (Daly et al. 2010; Potter et al. 2013). GIS techniques can be used when estimating the values of target variables between or around the weather stations (Virtanen et al. 1998).

(2) The inter-annual variability of temperatures in northern areas is very large. For example, in Finland the range of variation in monthly mean temperatures within a decade is $10-15^{\circ} \mathrm{C}$ during winter and about $5{ }^{\circ} \mathrm{C}$ during summer (Neuvonen and Viiri 2015). This variation is about an order of magnitude larger than the observed or projected decadal trends in temperatures.

\subsection{Birch Defoliators}

Cyclic outbreaks (8-11 year intervals) of defoliating Geometrids (E. autumnata, O. brumata) are typical for the mountain birch forests of north western Europe (Babst et al. 2010; Tenow 1972). In Finnish Lapland, the climate is more continental than in northern Sweden and Norway (Neuvonen et al. 2005), and low winter temperatures have historically reduced the regularity of outbreaks (Neuvonen et al. 1999). 


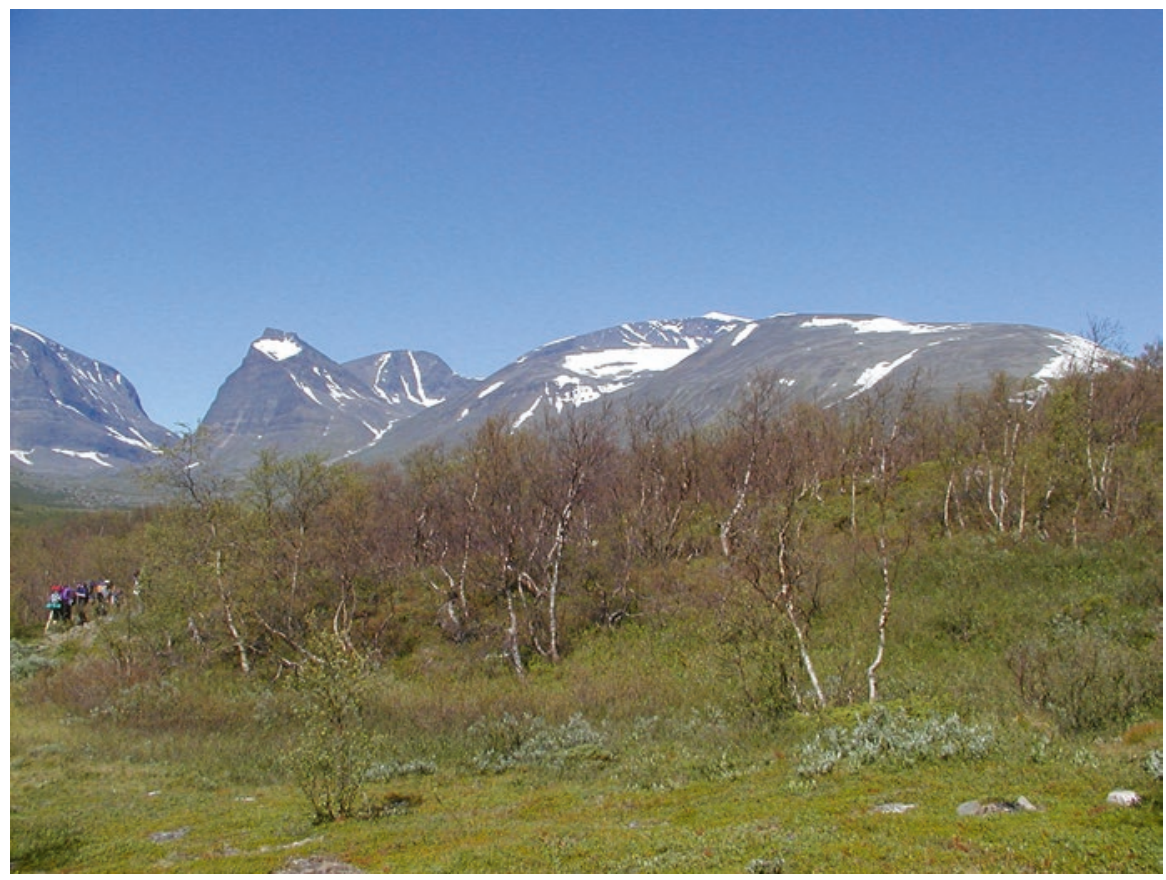

Fig. 5.1 Autumnal moth larvae have defoliated mountain birch forest in northern Sweden, affecting ecosystem services, local livelihoods, and the touristic value of the landscape (Photograph by Seppo Neuvonen)

The intensity of the peaks has varied considerably. The largest outbreaks have killed hundreds of square kilometres of birch forest (Seppälä and Rastas 1980). They can have devastating effects on ecosystem services and the condition of reindeer pastures (Biuw et al. 2014; Jepsen et al. 2013) (Fig. 5.1). Due to warmer winters that are not capable of killing the overwintering eggs, the incidence of outbreaks is predicted to increase in future in the continental areas of northern Europe (Ammunét et al. 2012; Virtanen et al. 1998). The number of defoliation years has increased because outbreaks of these two species have followed each other (Klemola et al. 2008).

The largest and most devastating outbreak was that of the mid-1960s in Utsjoki (the northernmost municipality in Finland), which changed very large areas of mountain birch woodland to secondary Tundra due to low recovery under heavy reindeer grazing pressure (Chapin et al. 2004a; Kallio and Lehtonen 1973). In the mid-1990s, the more southern parts of Finnish Lapland experienced birch defoliation, where old birches were attacked mainly at higher altitudes (Ruohomäki et al. 1997). In 2004-2005, mountain birch forests in Enontekiö (NW Finnish Lapland) experienced heavy defoliation but the birch forests apparently recovered quite well during the subsequent years (Kopisto et al. 2008).

The first recorded outbreak of Winter moth (O. brumata) in Finnish Lapland was at the start of this century (Jepsen et al. 2008). It caused serious defoliation of birch in a $400 \mathrm{~km}^{2}$ area in Kaldoaivi wilderness area in Utsjoki during 2006-2008 (Jepsen 
et al. 2009; Santonen 2011). There was no refoliation after this outbreak and dwarf shrubs were also destroyed in the ground layer. This caused extensive changes in ecosystem functions (Biuw et al. 2014) and societal impacts since reindeer pastures were damaged in large areas. This risked the sustainability of local livelihoods (Chapin et al. 2004b; Lempa et al. 2005).

\subsection{Pine Defoliators}

In northern Europe, the most common defoliating insects on Scots pine are N. sertifer, D. pini and Bupalus piniarius. Outbreaks typically occur in graded sandy soils; that is, on drier and less fertile forest sites (Larsson and Tenow 1984; Nevalainen et al. 2015). Regional $N$. sertifer epidemics have occurred every 10-20 years in southern Finland and this has caused the defoliation of large areas (Juutinen 1967). Although $N$. sertifer damage may look serious, forests typically recover because new shoots remain undamaged. Outbreaks occur at irregular intervals and normally they only last 2-3 years (Hanski 1987; Soubeyrand et al. 2010). The outbreaks end due to a virus disease of the pest and/or increased parasitism (Juutinen 1982; Olofsson 1987). Earlier, it was common to use biological control (Nucleopolyhedrosis virus) against $N$. sertifer (Juutinen 1982), but this virus is no longer allowed to be marketed in the EU.

Females of $N$. sertifer lay eggs into needles, where the eggs overwinter predisposed to low winter temperatures. The eggs can stand $-36{ }^{\circ} \mathrm{C}$ in mid-winter (Austarå 1971). Colder winter temperatures than this have been common in northern and eastern Finland, which has meant that outbreaks have been rare in these areas (Virtanen et al. 1996). An exceptional case is the $N$. sertifer damage at pine tree line areas in Saariselkä (Finnish Lapland) (Niemelä et al. 1987) where the eggs survive at higher altitudes due to strong temperature inversions in winter.

Normally the common pine sawfly $(D$. pini) causes more local, more irregular and more serious damage because the larvae gnaw all needle classes at the end of summer. If damage continues several years in the same area, then the mortality of trees increase and other pests such as bark beetles attack the trees (Annila et al. 1999). In Finland, the outbreaks of $D$. pini have been less common than those of $N$. sertifer, but during 1997-2000 there was an exceptionally large outbreak of $D$. pini in the central parts of the country (Nevalainen et al. 2010). A rough estimate was that pine forests experienced damage in an area of 500,000 ha, from which 200,000 ha had moderate to heavy damage (Varama and Niemelä 2001). The causes of this outbreak remain unknown.

It has been predicted that the outbreak range of $N$. sertifer will expand in eastern and northern Finland if winter minimum temperatures increase (Virtanen et al. 1996). However, this prediction does not apply to $D$. pini, which overwinters as cocoons in the soil, protected from cold temperatures by the snow cover. Furthermore, clear predictions about the population dynamics of pine sawflies in a changing climate might be impossible because the mortality rates are strongly affected by predation by small mammals (Hanski and Parviainen 1985), and the population dynamics of small mammals are complex and rather unpredictable. 
Fig. 5.2 Spruce bark beetles have first reproduced in storm damaged spruce trees (foreground), and during the following summer they have attacked and killed standing spruces (Photograph by Seppo Neuvonen)

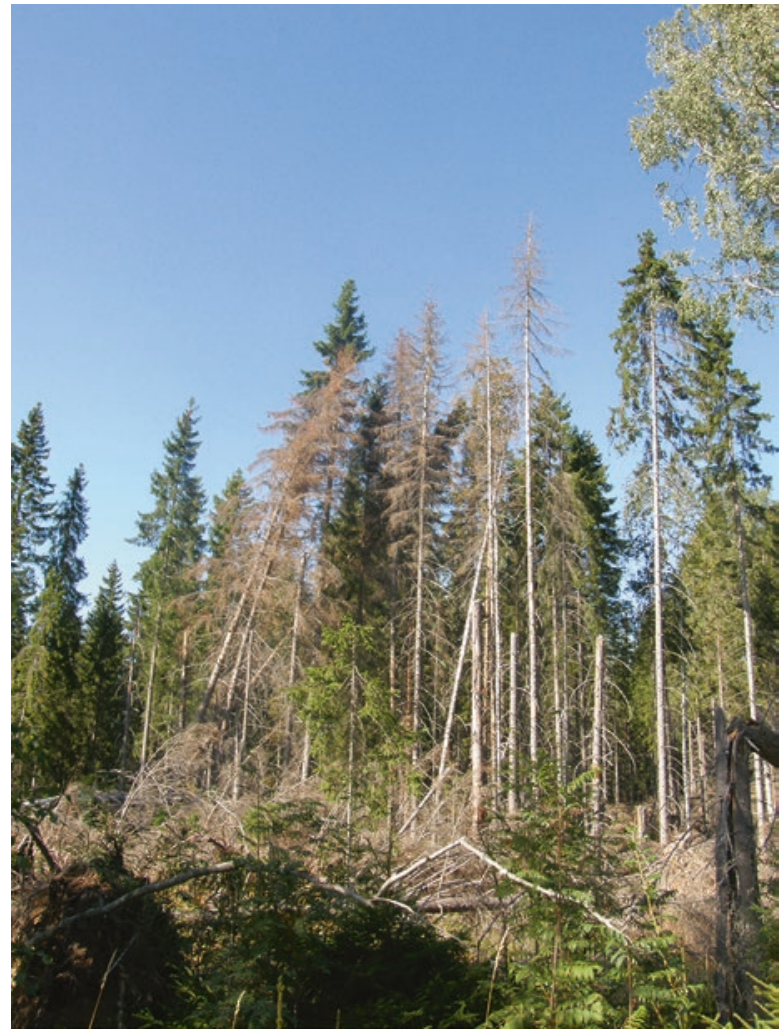

\subsection{Spruce Pests}

Spruce bark beetle, Ips typographus L, is the most severe pest on Norway spruce in Eurasia. It has caused remarkable forest damage in many European countries (Schelhaas et al. 2003). In Finland, spruce bark beetle damage has been at low level when compared to the other Nordic countries. However, from the year 2010 onwards, outbreaks of I. typographus and other bark beetles attacking spruce have increased in southern Finland. In summer 2010, thunder storms caused damage in large areas of central and eastern Finland. Parts of damaged trees remained in forest, which contributed to the growth of the population level (Viiri et al. 2011). Summer 2010 was also hot and dry in large areas of southern Finland, which lowered the resistance of spruce trees and predisposed them to bark beetle damage (Fig. 5.2).

Spruce bark beetle successfully breeds in fresh logged Norway spruce timber and windblown trees (Eriksson et al. 2008). It can attack healthy trees when the population level is high (Økland and Bjørnstad 2006). The risk of consequential tree deaths will increase considerably when the amount of windblown trees increases (Eriksson et al. 2007). Old growth forests, warm forest edges, fresh clear-cut borders and dry sites are especially vulnerable to damage. 
The second generation of spruce bark beetle was noticed for the first time in Finland in 2010 (Pouttu and Annila 2010). The development of the second generation remained mainly at larval and pupal stages, which cannot normally survive the winters in Finland (Annila 1969). Even though the bark beetle population size did not grow with new overwintering adults, more damage was caused by extra attacks on living trees. In addition, in southern Sweden there were observations of the development of two generations of spruce bark beetle after the Gudrun storm in 2005 (Långström et al. 2009).

The warming climate has made conditions more favourable to spruce bark beetle in the northern part of Europe (Økland et al. 2015). Longer growth periods and increased temperature sums have enabled the development of more sister broods and even the development of the second generation in some summers (Neuvonen et al. 2016; Wermelinger and Seifert 1999; Öhrn et al. 2014). Shorter periods of frozen ground and thunder-storms in the summertime have increased the amount of dead wood in the forests, which favours breeding bark beetles (Eriksson et al. 2007). Pheromone monitoring started in 2012 and it has shown that population levels have been at epidemic level since 2013 in many locations in southern Finland (Neuvonen et al. 2016).

\subsection{Conclusions and Future Prospects}

There are several sources of uncertainty when the impacts of climate change on pest insect outbreaks are predicted. First, the different global climate models and alternative emission scenarios produce large variation in predicted climatic outcomes (Jönsson and Bärring 2011; Ruosteenoja et al. 2016). Downscaling to regional and local levels and to microclimates brings more uncertainty to what will happen in the specific microhabitats where the pest insects are living (Neuvonen and Virtanen 2015; Potter et al. 2013).

Other types of uncertainty arise from the complexity on pest insect population dynamics. These are species specific, and include nonlinearities and time-delays, which may lead into chaotic dynamics (May 1976). Further complexities arise from the interactions among different trophic levels and the indirect effects of climate change via natural enemies (Davis et al. 1998; Virtanen and Neuvonen 1999b).

Given the difficulty in predicting climate change and its impact on insect outbreaks, the focus here is only on two systems where pests have the most important societal implications.

Geometrids Attacking Subarctic Mountain Birch Forests When multiple stressors like moth outbreaks and heavy reindeer grazing (Biuw et al. 2014; Tenow et al. 2005) reduce the resilience of the ecosystem, the changes can be drastic and almost irreversible (Chapin et al. 2004b). Reduced reindeer densities and changes in the seasonal patterns of grazing (pasture rotation) will be necessary for better sustainability of reindeer herding (Wielgolaski et al. 2005). 
Bark Beetles Attacking Norway Spruce The risk of bark beetle outbreaks will probably remain high in southern Finland in a warming climate (Viiri and Neuvonen 2016). The most efficient way to control spruce bark beetle damage is to remove damaged and attacked trees from forest before new progenies emerge (Stadelmann et al. 2013). In a warming climate, the reduction of spruce bark beetle risks with management actions (timely salvage and sanitation cuttings) is urgently required to guarantee the sustainability of forestry, especially because of the high economic importance of Norway spruce. Continuous monitoring of population levels and phenological surveys are needed for accurate risk estimates and as a basis for timely advice to forest owners about the best management practices (Viiri and Neuvonen 2016). Logging of trees that are windblown at summertime will be more urgent because the swarming time of spruce bark beetles is longer than it used to be (Neuvonen and Viiri 2015; Öhrn et al. 2014).

\section{References}

Aalto J, Pirinen P, Jylhä K (2016) New gridded daily climatology of Finland - permutation-based uncertainty estimates and temporal trends in climate. J Geophys Res-Atmos. doi:10.1002/2015JD024651

Ammunét T, Kaukoranta T, Saikkonen K, Repo T, Klemola T (2012) Invading and resident defoliators in a changing climate: cold tolerance and predictions concerning extreme winter cold as a range-limiting factor. Ecol Entomol 37:212-220

Annila E (1969) Influence of temperature upon the development and voltinism of Ips typographus L (Coleoptera: Scolytidae). Ann Zool Fenn 6:161-207

Annila E, Långström B, Varama M, Hiukka R, Niemelä P (1999) Susceptibility of defoliated Scots pine to spontaneous and induced attack by Tomicus piniperda and Tomicus minor. Silva Fenn 33:93-106

Austarå Ø (1971) Cold hardiness in eggs of Neodiprion sertifer (Geoffroy) (Hym, Diprionidae) under natural conditions. Norsk entom Tidsskr 18:45-48

Babst F, Esper J, Parlow E (2010) Landsat TM/ETM+ and tree-ring based assessment of spatiotemporal patterns of the autumnal moth (Epirrita autumnata) in northernmost Fennoscandia. Remote Sens Environ 114:637-646

Berryman AA, Stenseth NC, Isaev AS (1987) Natural regulation of herbivorous forest insect populations. Oecologia 71:174-184

Biuw M, Jepsen J, Cohen J, Ahonen SH, Tejesvi M, Aikio S, Wäli PR, Vinstad OPL, Markkola A, Niemelä P, Ims RA (2014) Long-term impacts of contrasting management of large ungulates in the Arctic Tundra-Forest ecotone: ecosystem structure and climate feedback. Ecosystems 17:890-905

Björkman C, Niemelä P (eds) (2015) Climate change and insect pests. CAB International, Wallingford

Chapin FS III, Callaghan TV, Bergeron Y, Fukuda M, Johnstone JF, Juday G, Zimov SA (2004a) Global change and the boreal forest: threshold, shifting states or gradual change? Ambio 33:361-365

Chapin FS III, Peterson G, Berkes F (18 authors) (2004b) Resilience and vulnerability of Northern regions to social and environmental change. Ambio 33:344-349

Daly C, Conklin DR, Unsworth, M.H (2010) Local atmospheric decoupling in complex topography alters climate change impacts. Int J Climatol 30:1857-1864

Davis AJ, Jenkinson LS, Lawton JH, Shorrocks B, Wood S (1998) Making mistakes when predicting shifts in species range in response to global warming. Nature 391:783-786 
Eriksson M, Neuvonen S, Roininen H (2007) Retention of wind-felled trees and the risk of consequential tree mortality by the European spruce bark beetle Ips typographus in Finland. Scand J Forest Res 22:516-523

Eriksson M, Neuvonen S, Roininen H (2008) Ips typographus (L.) attack on patches of felled trees: "Wind-felled" vs. cut trees and the risk of subsequent mortality. For Ecol Manag 255:336-1341

Hanski I (1987) Pine sawfly population dynamics: patterns, processes, problems. Oikos 50:327-335

Hanski I, Parviainen P (1985) Cocoon predation by small mammals and pine sawfly population dynamics. Oikos 45:125-136

Haukioja E, Neuvonen S, Hanhimäki S, Niemelä P (1988) The autumnal moth in Fennoscandia. In: Berryman AA (ed) Dynamics of forest insect populations: patterns, causes, and management strategies. Plenum Press, New York, pp 163-178

Hunter AF (1991) Traits that distinguish outbreaking and nonoutbreaking Macrolepidoptera feeding on northern hardwood trees. Oikos 60:275-282

Jepsen JU, Hagen SB, Ims RA, Yoccoz NG (2008) Climate change and outbreaks of the geometrids Operophtera brumata and Epirrita autumnata in subarctic birch forest: evidence of a recent outbreak range expansion. J Anim Ecol 77:257-264

Jepsen JU, Hagen SB, Hogda KA, Ims RA, Karlsen SR, Tommervik H, Yoccoz NG (2009) Monitoring the spatio-temporal dynamics of geometrid moth outbreaks in birch forest using MODIS-NDVI data. Remote Sens Environ 113:1939-1947

Jepsen JU, Biuw M, Ims RA, Kapari L, Schott T, Vindstad OPL, Hagen SB (2013) Ecosystem impacts of a range expanding forest defoliator at the forest-tundra ecotone. Ecosystems 16:561-575

Jönsson AM, Bärring L (2011) Future climate impact on spruce bark beetle life cycle in relation to uncertainties in regional climate model data ensembles. Tellus 63A:158-173

Juutinen P (1967) Zur Bionomie und zum Vorkommen der Roten Kieferbuschhornblattwespe (Neodiprion sertifer Geoffr.) in Finland in den Jahren 1959-1965. Comm Inst For Fenn 63:1-129

Juutinen P (1982) Vorkommen und biologische Bekampfung der Roten Kiefernbuschhornblattwespe (Neodiprion sertifer) in Finland. Allg Forstz 37:230-232

Kallio P, Lehtonen J (1973) Birch forest damage caused by Oporinia autumnata (Bkh.) (Lep, Geometridae) in 1965-66 in Utsjoki, N Finland. Rep Kevo Subarctic Res Stn 10:55-69

Kingsolver JG, Woods HA, Buckley LB, Potter KA, MacLean HJ, Higgins JK (2011) Complex life cycles and the responses of insects to climate change. Integr Comp Biol 51:719-732

Klemola T, Andersson T, Ruohomäki K (2008) Fecundity of the autumnal moth depends on pooled geometrid abundance without a time lag: implications for cyclic population dynamics. J Anim Ecol 77:597-604

Kopisto L, Virtanen T, Pekkanen K, Mikkola K, Kauhanen H (2008) Tunturimittarituhotutkimus Käsivarren alueella 2004-2007. Metlan työraportteja/Working Papers of the Finnish Forest Research Institute 76:1-24

Kouki J, Löfman S, Martikainen P, Rouvinen S, Uotila A (2001) Forest fragmentation in Fennoscandia: linking habitat requirements of wood-associated threatened species to landscape and habitat changes. Sand J For Res Suppl 3:27-37

Långström B, Lindelöw Å, Schroeder M, Björklund N, Öhrn P (2009) The spruce bark beetle outbreak in Sweden following the January-storms in 2005 and 2007. In: Insects and Fungi in Storm Areas, Proceedings Workshop of IUFRO Working Party 7.03.10, pp 13-19

Larsson S, Tenow O (1984) Areal distribution of a Neodiprion sertifer (Hym, Diprionidae) outbreak on Scots pine as related to stand condition. Ecography 7:81-90

Lempa, K, Neuvonen, S, Tømmervik H (2005) Sustainable reindeer herding in mountain birch ecosystem. Chapter 19 In: Wielgolaski F-E (ed) Plant ecology, herbivory and human impact in Northern Mountain Birch Forests. Springer Verlag, Ecological Studies 180:269-273

May RM (1976) Simple mathematical models with very complicated dynamics. Nature 261:459-467 
Mikkonen S, Laine M, Mäkelä H, Gregow H, Tuomenvirta H, Lahtinen M, Laaksonen A (2015) Trends in the average temperature in Finland, 1847-2013. Stoch Env Res Risk A 29:1521-1529

Neuvonen S, Viiri H (2015) Varautuminen lisääntyviin hyönteistuhoriskeihin muuttuvassa maailmassa. Kasvinsuojelulehti 4(2015):108-111

Neuvonen S, Virtanen T (2015) Abiotic factors, climatic variability and forest insect pests. In: Björkman C, Niemelä P (eds) Climate change and insect pests. CAB International, Wallingford, pp 154-172

Neuvonen S, Niemelä P, Virtanen T (1999) Climatic change and insect outbreaks in boreal forests: the role of winter temperatures. Ecol Bull 47:63-67

Neuvonen S, Bylund H, Tømmervik H (2005) Forest defoliation risks in birch forest by insects under different climate and land use scenarios in northern Europe. Chapter 9. In: Wielgolaski F-E (ed) Plant ecology, herbivory and human impact in northern mountain birch forests. Springer Verlag, Ecological Studies 180:126-138.

Neuvonen S, Tikkanen O-P, Viiri H (2016) Neljä vuotta kansallista kirjanpainajaseurantaa - feromoniseurannan tulokset 2015 ja muita havaintoja. Luonnonvara- ja biotalouden tutkimus 32(2016):28-32

Nevalainen S, Lindgren M, Pouttu A, Heinonen J, Hongisto M, Neuvonen S (2010) Extensive tree health monitoring networks are useful in revealing the impacts of widespread biotic damage in boreal forests. Environ Monit Assess 168:159-171

Nevalainen S, Sirkiä S, Peltoniemi S, Neuvonen S (2015) Vulnerability to pine sawfly damage decreases with site fertility but the opposite is true with Scleroderris canker damage; results from Finnish ICP Forests and NFI data. Ann For Sci 72:909-917

Niemelä P, Rousi M, Saarenmaa H (1987) Topographical delimitation of Neodiprion sertifer (Hym., Diprionidae) outbreaks on Scots pine in relation to needle quality. J Appl Ent 103:84-91

Nilssen A, Tenow O (1990) Diapause, embryo growth and supercooling capacity of Epirrita autumnata eggs from northern Fennoscandia. Entomol Exp Appl 57:39-55

Öhrn P, Långström B, Lindelöw Å, Björklund N (2014) Seasonal flight patterns of Ips typographus in southern Sweden and thermal sums required for emergence. Agric For Entomol 16:147-157

$\varnothing k$ land B, Bjørnstad ON (2006) A resource depletion model of forest insect outbreaks. Ecology 87:283-290

Økland B, Netherer S, Marini L (2015) The Eurasian spruce bark beetle: the role of climate. In: Björkman C, Niemelä P (eds) Climate change and insect pests. CAB International, Wallingford, pp 202-219

Olofsson E (1987) Mortality factors in a population of Neodiprion sertifer (Hymenoptera: Diprionidae). Oikos 48:297-303

Potter KA, Woods A, Pincebourde S (2013) Microclimatic challenges in global change biology. Glob Chang Biol 19:2932-2939

Pouttu A, Annila E (2010) Kirjanpainajalla kaksi sukupolvea kesällä 2010. Metsätieteen aikakauskirja 4(2010):521-523

Pouttu A, Silver T (2016) Pistiäistilanne: Yyterin tähtikudospistiäistilanne syksyllä 2015. In: Metsätuhot vuonna 2015. Nevalainen S \& Pouttu A (eds). Luonnonvara- ja biotalouden tutkimus 32/2016: 8-27

Ruohomäki K, Virtanen T, Kaitaniemi P, Tammaru T (1997) Old mountain birches at high altitudes are prone to outbreaks of Epirrita autumnata (Lepidoptera: Geometridae). Environ Entomol 26:1096-1104

Ruosteenoja K, Jylhä K, Kämäräinen M (2016) Climate projections for Finland under the RCP forcing scenarios. Geophysica 51:17-50

Santonen T (2011) Mittarituhot pohjoisen Utsjoen alueella ja sen vaikutukset alueen kasvillisuuteen ja poronhoitoon [Winter moth outbreaks in northernmost Fennoscandia and effects to vegetation and reindeer husbandry]. Thesis, 35 pp. Jyväskylä University of Applied Sciences, Finland

Schelhaas M-J, Nabuurs G-J, Schuck A (2003) Natural disturbances in the European forests in the 19th and 20th centuries. Glob Chang Biol 9:1620-1633 
Seppälä M, Rastas J (1980) Vegetation map of northernmost Finland with special reference to subarctic forest limits and natural hazards. Fennia 158:41-61

Soubeyrand S, Neuvonen S, Penttinen A (2010) Mechanical-statistical modeling in ecology: from outbreak detections to pest dynamics. Bull Math Biol 71:318-338

Stadelmann G, Bugmann H, Meier F, Wermelinger B, Bigler C (2013) Effects of salvage logging and sanitation felling on bark beetle (Ips typographus L.) infestations. For Ecol Manag 305:273-281

Tenow O (1972) The outbreaks of Oporinia autumnata Bkh, Operophthera spp (Lep, Geometridae) in the Scandinavian mountain chain and northern Finland 1862-1968. Zool Bidr Uppsala Suppl 2:1-107

Tenow O, Bylund H, Nilssen AC, Karlsson PS (2005) Long-term influence of herbivores on northern birch forests. Chapter 12. In: Wielgolaski F-E (ed) Plant Ecology, Herbivory and Human Impact in Northern Mountain Birch Forests. Springer Verlag, Ecol Studies 180:165-181

Varama M, Niemelä P (2001) Männiköiden neulastuholaiset [The defoliators in Scots pine forests] Metsät aikak 2/2001:275-279

Viiri H, Neuvonen S (2016) Kirjanpainajasta on tullut pysyvä ongelma Suomen kuusimetsille Mitä olisi tehtävä? Kasvinsuojelulehti 2(2016):57-61

Viiri H, Ahola A, Ihalainen A, Korhonen KT, Muinonen E, Parikka H, Pitkänen J (2011) Kesän 2010 myrskytuhot ja niistä seuraava hyönteistuhoriski. Metsät aikak 3(2011):221-225

Virtanen T, Neuvonen S (1999a) Climate change and Macrolepidopteran biodiversity in Finland. Chemosphere Global Change Sci 1:439-448

Virtanen T, Neuvonen S (1999b) Performance of moth larvae on birch in relation to altitude, climate, host quality and parasitoids. Oecologia 120:92-101

Virtanen T, Neuvonen S, Nikula A, Varama M, Niemelä P (1996) Climate change and the risks of Neodiprion sertifer outbreaks on Scots pine. Silva Fennica 30:169-177

Virtanen T, Neuvonen S, Nikula A (1998) Modelling topoclimatic patterns of egg mortality of Epirrita autumnata (Lepidoptera: Geometridae) with a Geographical Information System: predictions for current climate and warmer climate scenarios. J Appl Ecol 35:311-322

Voolma K, Pilt E, Õunap H (2009) The first reported outbreak of the great web-spinning pinesawfly, Acantholyda posticalis (Mats.) (Hymenoptera, Pamphiliidae), in Estonia. Forestry Studies/Metsanduslikud Uurimused 50:115-122

Wermelinger B, Seifert M (1999) Temperature-dependent reproduction of the spruce bark beetle Ips typographus, and analysis of the potential population growth. Ecol Entomol 24:103-110

Wielgolaski F-E, Karlsson PS, Neuvonen S, Thannheiser D, Tømmervik H, Gautestad AO (2005) The Nordic mountain birch ecosystem - challenges to sustainable management. Chapter 25 In: Wielgolaski F-E (ed) Plant ecology, herbivory and human impact in northern mountain birch forests. Springer Verlag, Ecological Studies 180:343-356

Williams CM, Henry HAL, Sinclair BJ (2014) Cold truths: how winter drives responses of terrestrial organisms to climate change. Biol Rev 90:214-235

Open Access This chapter is licensed under the terms of the Creative Commons Attribution 4.0 International License (http://creativecommons.org/licenses/by/4.0/), which permits use, sharing, adaptation, distribution and reproduction in any medium or format, as long as you give appropriate credit to the original author(s) and the source, provide a link to the Creative Commons license and indicate if changes were made.

The images or other third party material in this chapter are included in the chapter's Creative Commons license, unless indicated otherwise in a credit line to the material. If material is not included in the chapter's Creative Commons license and your intended use is not permitted by statutory regulation or exceeds the permitted use, you will need to obtain permission directly from the copyright holder.

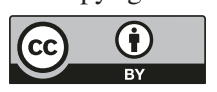

